\title{
MAKING BODY POLITIC: \\ THE RHETORIC OF EARLY CHRISTIAN \\ BAPTISMAL DISCOURSE
}

Gerhard A van den Heever

University of South Africa

\begin{abstract}
This article considers contemporary baptismal discourse in a Reformed theological context in its relation to early Christian baptismal practice and discourse. It is argued that whereas Reformed baptismal discourse presents the ritual as connection with divinity, early Christian baptismal practice had a primarily social function. Early Christian baptism was a way of constituting a new "body politic." The difference between the two types of baptismal discourse is an effect of the different social functions of the two religious discourses in different contexts. The changing nature of religious performance as demonstrated via different conceptions of baptism, illustrates - and undergirds - a social theory of religion.
\end{abstract}

Keywords: Rhetoric, Performance, Ritual, Baptism, Early Christianity

\section{Rhetoric and Performance}

Rhetoric is more than speech or text, although most studies of rhetoric approach the subject as a textual or lingual phenomenon. This means, simply, that what constitutes the focus for an analysis of the rhetoric of the text or speech, is the complex arrangement and assembly of textual (rhetorical) elements - the tropes, topics, styles and formal argumentative features of the rhetorical "artifact," be that a text or speech. This is, of course, not surprising, since often this is all that remained of the original rhetorical event (and given the setting of this enterprise, namely in the academic context, this is what scholars do - they read texts). This holds true especially of ancient documents and other artifactual remains, whereas, by contrast, in the case of contemporary rhetorical events and practices we can draw on a wider array of resources for the construction of the rhetoric, such as photographs, sound and video recordings. In these cases the conceptualisation of the rhetoric can be broadened to include such "analogic" communication strategies or "information" elements as the context and setting, bodily gesture, tone of voice, and facial expression. The rhetorical event is therefore a conjunction of two simultaneous communication processes - the "digital" which refers to the verbal content (which includes the overt rhetorical elements of trope, topic, style and argument structure), and the "analogic" process (Watzlawick, Bavelas and Jackson 1967, 60-67; Van den Heever 2002, 302-304). If all communication contains report and command aspects, that is data plus instructions as to what to make of/with the data (Watzlawick, Bavelas and Jackson 1967, 52; Van den Heever 2002, 303) implying the essential rhetoricity of all communication - and if the combined reportcommand derives its rhetorical force from "enacted elements-placed-in-context" then it should be clear that what lies outside of the rhetorical artifact (the speech or text) is equally 
important for and determinative of the construction of reality effected by the rhetorical act/event. ${ }^{1}$ Simply put, the rhetoric is constituted by a contextualised performance.

The relationship between text and context, or between text and performance, is a complex one, and one that demands a thorough conceptualisation of the interplay between text, context, ritual/performance, and (rhetorical) discursive formations as means of constructing social formations. ${ }^{2}$ In contrast to earlier scholarly conceptualisations that held that the text represents or reflects ritual practice, or that ritual is the enactment of a textual script (Bell 1998, 205-206, 208; Bell 1988, 368), Catherine Bell (in most of her writings on ritual and performance) draws attention to the way in which "the medium is the message" (Bell 1988, 369 ), that is, the agency function of texts in an attempt to overcome the dichotomy of thought and action inherent in older, and conventional, understandings of both rhetoric and ritual. By "agency function" is meant the way in which a text functions as a medium in the process of human construction of culture, society, and world. ${ }^{3}$ In the case of religious texts this takes place through a process of "ritualisation" and "textualisation." Ritualisation refers to the "orchestration of ritual activities to serve as the medium of interaction for a particular set of social relations" (Bell 1988, 390), literally, how a social formation is constituted and structured is defined by the use of the text (and not only the contents) by which the access to the sacred or the cosmological order is enacted. It concerns the way in which images, symbols, traditions (textual and otherwise), epic, myth (as identity-giving narratives), habituated actions and fixed and formalised performances are configured to create, arrange and maintain social relations that would not otherwise have arisen. Textualisation refers to "the generation of textual objects that structure social interactions around their use and transmission" (Bell 1988, 390). Textualisation signifies a move away from "pure action" to the directive character of text as interpretation of the event/performance and text as directions for event performance. While the term ritual normally evokes a sense of the immutable, the fixed and unchangeable, ritual as performance is actually a highly innovative and creative process. Rituals are not only adapted to new circumstances and contexts, the ritualised texts and textualised rituals themselves are constantly reinterpreted and rhetorically reconfigured to address the demands of new social formations, world and mythmaking (or the conceptualisations of such, for the perceived demands of the context do not exist objectively - they are projected as this or that).

1 The reference to the "outside of the text" concerns the notion put forward by Wilhelm Wuellner (1991, 171185) that "what comes before and after the text" is part of the rhetoric of the text and its interpretation, which notion was broadened to include, apart from the temporal outside, also the spatial outside of the text cf. Van den Heever $(2002,298)$.

2 For a conceptualisation of the issues raised in this article I drew on the work of Catherine Bell, in this context especially Bell (1998 and 1988) and Goldberg (1990) (the latter an application of Bell's work to a study of the ritualisation of the Zohar among Jewish communities in southern Morocco).

3 In Bell's view, "performance" refers to the human act of creating meaning "from the raw happenings of life" (Bell 1998, 212); "ritual," in this connection, would denote habituated and routinised acts whereby traditions and conventions are manipulated in order to construct an understanding of the situation (Bell 1998, 217). One can go even further: ritual as performance is a particular species of world-making and social formation in that the inter-action with the configured symbols evoke a cosmos as context, and simultaneously create - and maintain - the enveloping cosmos for the participants.

4 Bell's (1988) study "Ritualization of Texts and Textualization of Ritual in the Codification of Taoist Liturgy" is a study of the particular ritual innovations to the Ling-Pao scriptures codified by Master Lu (407-477), creating both an incipient Taoist orthodoxy and class of ritual mediators or religious specialists. Textualising the ritual intensified the talismanic character of the text/s so that the textual tradition itself fulfilled the role of religious intermediary agency yet at the same time widened access to the Ling-Pao scriptural tradition. Harvey Goldberg's study (1990) on the Zohar focusses on a similar phenomenon. In this study he shows how the text of the Zohar comes to function as divine intermediary agency in much the same manner as relics in the Christian veneration of saints. 


\section{Christian Baptism as Performance: From Social Formation to Divine Presence}

The history of the rhetoric of the Christian rite of baptism constitutes a good testing ground for this theory of "performance rhetoric." Any study of the history of baptismal rhetoric and baptism discourse will show that all of the early Christian texts that speak of baptism are in some way or another textualising practices of social demarcations through purification symbols, and are simultaneously ritualising these texts by virtue of their instructional character. ${ }^{6}$ The precise, historical origins for the ritual of baptism are now lost in the mist of time, but the prevalence of purificatory rituals of water washings and lustrations in Graeco-Roman antiquity among groups conventionally designated as "mystery cults" as well as among early Christian groups both "heterodox" and "orthodox," or "mainstream," suggests that issues of purity and purification were main concerns in "new religious movements" in late antiquity. ${ }^{7}$ Purity and purification in this context have less of a "theological" meaning than a social and anthropological significance. ${ }^{8}$ New social identities and social formations are constituted in the act of washing as dissociating from the outside world. ${ }^{9}$ The fact that these cult groups flower at the onset of the Roman Empire

5 In her book Ritual Theory, Ritual Practice, Catherine Bell (1992) indeed comes to consider baptism as performance and rite.

6 It would be impossible in the context of this article to give an extensive overview of all the texts mentioning baptism in its many guises (because one should connect actions like oil chrisms also with water baptism as happens often in gnostic texts), but one can refer as examples to the Letter to the Colossians $(2: 11-15 ; 3: 10), 1$ Peter (3:18-22, a paraenetic context), 1 Corinthians (6:11, also a paraenetic context), as well as Titus (3:5); outside the New Testament see Didache 7, Gospel of Philip (60ff.), Traditio Apostolica (20-21), Cyril of Jerusalem Mystagogical Catecheses, John Chrysostom Baptismal Catecheses, the Syriac Didascalia Apostolorum, Theodore of Mopsuestia Liber ad Baptizandos, and so on. Of particular interest is NHC III The Holy Book of the Great Invisible Spirit or The Egyptian Gospel (IV 76ff.), for the paradigmatic manner in which the baptismal liturgy is embedded in and constitutes the climax of a vision of the divine realm. Also, in a wider context, baptismal rites (often of a quite complex nature and many-layered) are known for Elkesaite and Mandaean groups (in fact, there seems to have been a widespread phenomenon of Jewish-Christian millennialist baptist groups in the region east of the river Jordan in late antiquity). What I want to draw attention to is that these texts mention baptism in a context of liturgical and paraenetical instruction.

I have omitted from the discussion those texts in which baptisms are mentioned as illustration or as part of the narrative, like the Acts of Thomas (121 - the baptism of Mygdonia), or in polemical context like Irenaeus Against Heresies (e.g., I.21.4) or Hippolytus Refutation of All Heresies.

On the issue of baptism in early Christianity and for a fuller treatment (as well as further literature), see Jonathan Z. Smith's (1978, 1-23) essay "Garments of Shame"; see also Rudolph (1987, 226-230) on baptisms and washings in gnostic groups. For an overview of baptismal practices in "heretical" groups in the second century, cf. Marjanen and Luomanen (2005, 32-61, 89, 271, 341, 353-356).

7 But see Walter Burkert's (1987, 101-102) caveat on the interpretation of the evidence for "baptisms" in ancient mystery cults. However, standing back at a distance and looking at "new religions" or "new religious movements" in antiquity it is remarkable how water-based purificatory rites do feature constantly in these cults, contra Reitzenstein (1956 [1927], 233-234) - also among modern, contemporary new religious movements - and it is this feature that arouses my interest.

8 A phenomenon illustrated by the social discursivity of baptism as simultaneously a rite of changing identity, hence the ancient custom of changing clothes during the baptismal ritual, see Smith (1978). This is amply illustrated by the new identity of the resulting Christian social entity as "wearing the new humanity" as a new set of clothes, cf. Col 3:10; Eph 4:24; and Rom 13:14.

9 This is also the meaning of the oil chrisms as exorcisms practised in early Christian baptismal liturgies (including heterodox liturgies such as found among the gnostics). Being removed from the authority of evil spirit beings (whether Satan or other angelic beings) the baptised is cut off from the powers that rule the world. It is an opting out of the "way things are," or the culturally accepted, ordinary human arts de faire (cf. Traditio Apostolica 20-21). This is evidenced not only in the way women have to give up jewellery and coiffure, but also in the many occupations that would disqualify prospective initiants from being baptised (Traditio Apostolica 16). As the example from the Traditio Apostolica demonstrates, purity implies difference from the greater surrounding society, see also the evidence of the constitution of the Philadelphian cult group discussed by 
(roughly from the late Republic through the fourth century C.E.) is indicative of the vast project of social redefinition necessitated by the cessation of native kingdoms with the attendant destruction of traditional societies resulting in a variety of diasporas. ${ }^{10}$

Historically, I would contend, purity and purification as discourses of social formation (one could say, as social ideology) constitute the original meaning of the manifold rites of washing and lustrations or baptisms in late antique cult groups including early Christianity, and this layer of meaning is still visible in some early Christian texts. In this they represent what scholars of religion call critical religion as opposed to primal religion (Pye 1995, 815; Cumpsty 1995, 20-24, 32-36). "Primal religion" is religion that is "coterminous with a specific, natural society" whereas critical religion stands in "some tension to natural society and offers a differentiated perspective upon it." In the case of primal religion, society, culture and religion are highly interwoven so as to be indistinguishable as was the case with traditional Graeco-Roman religions. Critical religion implies a world orientation that requires some distancing from mainstream society. Allegiance in this regard is acquired by opting out of naturally obtaining relations, from society or family and kin. Critical religion is founded on counter-intuitive insights into what counts as ultimately real and meaningful and constitutes a redefinition of the individual's position vis-à-vis the larger society as well as a critique of that society. Socially it institutionalises artificial communities based on newly or redefined, fictive kinship. Such religions, as non-natural societies, are also "soteriological religions" since their raison d'etre is to "save from," and they do so by creating societies within society. The ritual mechanisms by means of which this is accomplished are rituals of incorporation and rituals of enforcement. ${ }^{12}$

If the original purpose of the surface discourse of purity/purification coupled with the performance of habituated actions was to serve social formation as alternative worldmaking, in the course of Christian history this discourse came to be overlaid by another mythicising discourse - the juxtaposition of mythemes of a "dying and rising god" to the performance of purification and social constitution. ${ }^{13}$ The rhetoric of baptismal discourse resides in the manipulation of symbols, images, and epic (as overarching mythical narrative constituted by selected narratives-as-examples) ${ }^{14}$ in order to adapt existing social

Barton and Horsley (1981). The long lists of sins, Lasterkataloge, of early Christian writings (e.g., Eph 4:1732; Col 3:5-9; Gal 5:19-21; Didache 5) makes sense in this context.

10 On this topic, see especially Versnel (1988b, 116-117, 122-129). By way of comparison one can point to Stephen Hunt's (2003) study of alternative religions in Britain: the flowering of alternative religions and cults are indicative of the fracturing of society as a result of and in the aftermath of the British Empire - many of these alternative religions and cults are configurations of and rooted in diasporic traditions. And a good many are just newly constituted bricolages of diverse exotic elements.

11 See also Van den Heever $(2001,11)$ for an interpretation of this twofold typology and its relevance for theorising religious identity.

12 The complex process of initiation by investigation (as to suitability), purification/washing, exorcism, chrism - the baptismal process - is an early Christian example of incorporation rite. But it was by no means unique to early Christianity, the account of Lucius's initiation into the cult of Isis in Apuleius's Metamorphoses, or The Golden Ass evidences the same process. The eucharist and confession would be examples of rituals of enforcement.

13 E.g., Col 2:12-13, baptism is incorporation into the fate of Jesus Christ, that is, dying and rising with him; similarly Rom 6:3-11; less elaborate but nevertheless telling, Didache 6 - to baptise in the threefold name of the Father, Son and Holy Spirit, with all the associations these evoke; baptism as divinisation, Irenaeus Against Heresies I.21.3, of the Valentinian view of the rite as union with the divine; also the attainment of immortality by acquaintance the incorruptible beings, the baptismal liturgy in The Holy Book of the Great Invisible Spirit (76-80).

14 Epic refers to the way in which a set of stories and symbols with respect to the past are imagined to relate to the present (Reed 1996, 130). 
performances for a new construction of the cosmos. ${ }^{15}$ It should be understood, however, that performances of purification as social formation were never purely secular (an anachronistic concept with regard to antiquity), that is, in antiquity they were always connected to the world of gods as representation of the well-ordered cosmos. Rhetoric is always the manipulation of symbols, but the novelty here lies in the gradual occulting of the social function of the performance or ritual behind the symbol set of divine epiphany as cosmic centre. ${ }^{16}$ In this new "cosmology" the location of epiphany has been decisively shifted from the public sphere of the traditional (polis) cults with their institutions of social maintenance, to the enclosed sphere of voluntary societies of purified initiates, but exactly in this lies its rhetorical significance: It recreates from old performances a new presence of and access to divinity. Literally, the rhetoric of baptismal discourse fashions a new cosmology, a new world through the changed interpretation of performances of purification and social formation. The practices and performances are textualised in new reinterpretations that again, as instructional texts, ritualise the new cosmology and participation in it.

"The fashioning of a new cosmology" centred on divine epiphany is what sacramental theology is all about. Although the two terms mystêrion and sacramentum do not occur in the later, conventional sense of cultic act in either Hellenistic Jewish writings or in the New Testament, nor in the Apostolic Fathers, they gradually acquired the meaning of ritual act in the writings of the Apologists as a result of the confrontation with Gnosticism and mystery religions (Wenz 1998, 665). In the later second century and early third century Christianity, under the influence of pagan cultic celebrations, the two terms came to be understood as ritual performance of a divine drama first and foremost, so that mystêrion and sacramentum acquired the meaning of symbolic representation of a divine salvific act in the history of Jesus Christ, and consequently became technical terms for Christian cultic performances (Wenz 1998, 665). In this, early Christianity resembled the so-called mystery religions, for the defining characteristic of Graeco-Roman mystery cults of the imperial era was that of performance of dramatic rituals ("things performed," drōmena, or a mime pageant called a drama mystikon) - religion as pageantry, as tableau vivant. Religion was the (often largescale) performance of narratives about gods. ${ }^{17}$ That Christianity came to resemble this in the fourth century, is evidenced by the elaborate baptismal liturgies described for the Jerusalem Easter octave by Cyril of Jerusalem and Egeria (see below).

Augustine was the first to develop a sign theory for the sacraments, defining the sacrament as a sign pointing to divine reality (Wenz 1998, 665), the real presence of divine reality only evoked into connection with the sacramental elements by the accompanying, defining, mythicising words or formulae (Accedit verbum ad elementum, et fit sacramentum, etiam ipsum tamquam visibile verbum; "The word is added to the element, and there results the sacrament, as if itself also a kind of visible word" - the famous Augustinean formulation, from Tractates on the Gospel of John 53.3, on John 15:1-3) (Wenz 1998, 666). However, later developments went into the direction of a conception of a much closer connection between signum and res divina, towards a more realistic understanding of the sacraments under the influence of a "sensualist worldview" (Wenz 1998, 667). Following on the eucharistic controversy in the 11th century between Lanfranc and Berengar of Tours,

15 The latter phrase is borrowed from Henk Versnel (1988b, 127).

16 In early Christian literature both meanings - purification as social formation and epiphany of cosmic centre are visible. In 21 st century Christianity the process has been completed, social formation is no longer in view; see below.

17 On this aspect, see Van den Heever (2005). The Telestērion at Eleusis could, at its zenith, house a few thousand spectators on stands around a large open space for the performance of mime-pageants. 
the Berengarian view of the presence of the "real thing" (non solum sacramento, sed in veritate, "not only in the form of the sacrament but in truth/reality") (Wenz 1998, 667) became dominant in Christian sacramental theology - eventually with Thomas Aquinas formulating the statement that the sacraments "effect what they signify" (efficiunt quod figurant) (Wenz 1998, 668), literally: They cause grace and salvation.

The point of this short overview of the history of sacramental "theory" in Christianity is to show how more and more ritual performances and celebrations were understood to erect, or create the sacred in the presence of the religious community, to construct a divine, cosmological order for the "initiated" to live in. And also to show how the earlier primary social meaning gradually got subsumed under a more "vertical" understanding of the effect of the performance.

\section{Reformed Theology and Sacramental 'Rhetoric'}

Christian baptism is a sacrament - that is, it is a vehicle for salvation through which the one baptised is connected with deity. It is this aspect of baptism, namely the connection between baptised and deity, that dominates most mainline churches' understanding of the rite. Though it should be said that this "connection" is conventionally considered to be of a fairly loose nature, the result of the fuzzy language in which Reformed baptismal understandings are clothed, baptism not being the reality of salvation, nor not-salvation, but something undefined, or rather underdefined, and unreflected. ${ }^{18}$

I was recently reminded of this at a baptismal service in our local church (Dutch Reformed Church, Pretoria East, 1 August 2004; the minister was Rev. Marina Strydom, who kindly furnished me with a copy of the sermon notes). During the sermon itself the minister emphasised moral formation as the basis for Christian identity as the broader context for the understanding of the baptism that was to follow. Moral formation was addressed in the context of contemporary society in which identity is formed/created/ maintained through adherence to "socio-economic" brands, whether that be clothes, fashion accessories, motor cars, other trappings of wealth and class identifiers. In doing this the minister stayed true to much of New Testament discourse on baptism in which references to baptism regularly occur in contexts of moral exhortation. But the interesting part came when the baptismal liturgy itself started. At this point the minister shifted into a different gear: The minister took pains to emphasise that baptism is not the giving of a Christian name, nor a vow made by the parents to educate their child to be a Christian, and so on - all

18 In a rhetoric of inquiry the "inquirer"s' own experience has to be reflected on and theorised. My connection to the question posed here derives from my own experience as a young, newly ordained minister of the Dutch Reformed Church when, shortly after my ordination I had to conduct a baptismal service. During the preparation for this I became acutely aware that my theological training, especially as far as baptismal theology went, left me completely unprepared to answer the questions raised about the sacrament in a context long devoid of ritual consciousness, celebration, and appreciation. Drawing on the material prescribed during my student years in order to prepare the baptismal service I found to my dismay that the vagueness of the language was of no help as one remains in the dark as to what is given or not given in the act of baptism, that is what happens or does not happens in the practise of the rite. (This is, incidentally, a question that has plagued all debate in the Dutch Reformed Church about baptism, especially in the contrast between infant baptism and faith- or confession baptism of adults.) The situation called for some exegetical delving into the understanding of baptism in the New Testament and early Christianity, in which I was greatly helped and inspired by such writers as Manfred Seitz (1976), Ferdinand Hahn (1976), and Gerhard Barth (1981). I was, therefore, completely taken by surprise to experience the vehemence with which my "realist" understanding of baptism was attacked with views bordering on pentecostal understandings of baptism (and this in a Reformed setting) - one female member of the congregation even went as far as saying baptism (and this for infants!) is only the parents' promise to raise their children Christian. 
actual examples of folk understandings of the rite of baptism. Instead, so the minister argued, baptism is something that God performs on the child or person baptised proclaiming his love for the baptised person, offering and asserting his present and future involvement in the life of the baptised. The minister preached good conventional Reformed covenantal theology, but what gripped my attention was the difference postulated between the folk understandings of baptism and the theological understanding of the rite, more specifically the rhetorical construction of baptism as a ritual in a Reformed context, as well as the difference between this and early Christian baptismal discourse.

To use an example: In the current baptismal liturgy of the Dutch Reformed Church (infant) baptism is justified with reference to the covenant of grace (Gal 3:29; Rom 4:11, 16; and Gen 17:7) understood as the promise of God's presence and involvement in the life of the baptised; baptism being the New Testament/Christian sign and guarantee of the covenant; and being performed in obedience to the command of Jesus Christ himself (Matt 28:19, 20a). The baptismal formulary concludes the justification with the words: "In this manner the Lord pledged through the covenant to be our God and to bless us."19 And then the formulary continues with a set of propositions that define its understanding of what baptism is all about:

- We were all born as sinners and will only enter the kingdom of God if we are reborn;

- Baptism confirms that we are included in the covenant and partake of all the privileges of the covenant;

- Baptism conveys that we have all been linked/connected to Christ who has washed away our sins through his blood;

- That we have been crucified with Christ, dying to the old sinful life, and resurrected with him into a new life;

- Baptism being a seal of incorporation into the church of Jesus Christ obliges us to a life of active membership;

- That the baptised should love the Lord with their whole being, out of gratitude, with a view to a life of service;

- And that the Lord ensures the baptised through the sacrament that He wants to live in the believer through the Spirit with a view to making the baptised believer more godlike.

Note the almost exclusive focus on the relationship between deity and the baptised, as well as the fuzzy language in which this talk is clothed (what can be the practical, concrete experience of being in the covenant? In what way can the reality of having died and being resurrected with a "non-obvious being" be conceived at all?). The question is almost inescapable: Did you get anything or not, and if so, what?

And then, just before the infant is baptised, in order for the parents to confirm that they hold the above-mentioned ideas about baptism to be true, they have to assent to the following propositions:

- First, that although children come into the world as sinners and as such are under God's judgement, they nevertheless belong to God in Christ and should be baptised as members of the church;

- Second, that the teaching of the Old and New Testaments, as encapsulated in the articles of Christian faith as it is taught in the church, is the true and complete doctrine of salvation;

- And third, that the parents undertake to educate the child in this doctrine.

19 "So het die Here Hom verbind deur hierdie verbond om ons God te wees en ons te seën." [59] 
The net effect of this baptismal formulary as it is enacted is to remove the act of baptising wetting the forehead of the infant - from the domain of bodily enactments and placing it within a framework of cognitive assent to assertions or propositions. That this is so can be seen in the absolutely minimal use of water in the administering of baptism, so that it can no longer be said to signify a washing as is stated in the formulary itself with the phrase "washed in Christ's blood." In fact, anecdotal evidence would suggest that, when asked, most church members would say that the element of wetting the forehead "is only symbolic," meaning by that "it is only an empty symbol," it could have been anything else - there is no necessary meaning in the water rite. The material element is "etherealised," it disappears from view. And when the same parents would be asked to say what the meaning is of the baptism of their child (and this was my experience in the ministry), the answer is almost invariably something as vague and general as "God loves my child." An insight and conclusion for which you did not need a ritual.

So whatever interpretation is attached to the ritual of baptism in baptismal theology, however much it is attempted to control and redirect the folk understanding of the ritual, very little of this succeeds (at least here in our context). In general, folk understanding of baptism continues to hold baptism to be a social celebration of the arrival of a/the/another child in the family. It is therefore mainly a cultural phenomenon. I have a theory about why this is so, which I will state at the end. But for now it should be pointed out that Dutch Reformed baptismal theology is partly responsible because of its shifting of the focus away from the material rite to the cognitive contents of the attendant theological propositions.

Now, what makes this phenomenon so interesting is the fact that both contemporary Reformed baptismal theology and folk understanding of baptism lie completely at odds with early Christian understanding of baptism.

\section{Early Christian Baptism as a Social Discourse}

When one considers the contexts in which references to baptism occur in the New Testament (1 Pet 3:18-22 [21]; Col 2:9-15 [12], 3:9-10 [implied]; 1 Cor 6:11; Titus 3:5) it is clear that these are all contexts of moral exhortation and purification. These are not instances of moral injunctions in general, but specifically exhortations to break with a clearly delineated lifestyle and sets of actions, variously called "life without/before Christ," "life in sin," or "pagan lifestyle," and to embrace a newly defined lifestyle that is the embodiment of divinity. So there is a very strong sense of new lifestyle being part of and understood as social formation. We are therefore looking through a window at the period of making Christendom. Early Christianity is literally exhorted and ritually performed into being. This is the rhetorical aspect of the making of early Christianity, but whether anyone actually lived like this, is not possible to tell.

This is borne out further in the Didache, where the chapter on baptism (7) follows on the first 6 chapters containing the Two Ways instruction, which too contains a strong element of "lifestyle bifurcation" ("way of life" vs. "way of death"). It is illuminating that this section begins with the words "when you have rehearsed all these things" (i.e., the Two Ways instruction). So the Two Ways tractate in the Didache is not just a kind of moral baptismal catechesis, but a lifestyle coach into a newly constituted society - the Didache functions as a kind of church order. The long moral instruction found in the Two Ways tractate that precedes the baptism is effectively a kind of ritual process of separation and preparation for baptism. If there is any significance to the order of chapters in the Didache, it should be illuminating then that the section on baptism is followed by the eucharistic 
liturgy of chapters 9 and 10, which constitutes the communal meal at which the baptised are incorporated into the community. ${ }^{20}$

Using the Didache as a point of comparison, one can further consider the use of a similar Two Ways tractate in the Manual of Discipline of Qumran (1QS III.18-IV.20). Here one finds an even stronger emphasised context of purification, and the numerous references to purificatory washings in this very section ${ }^{21}$ suggest, I would contend, that we are essentially looking at a similar moral coaching-water washing-social formation complex that we find in early Christian texts.

Not only is this a strong purificatory setting, but the social meaning of purification is equally strongly suggested: "He would swear by the covenant to be segregated from all the men of sin who walk along paths of irreverence... He should not go into the waters to share in the pure food of the men of holiness, for they have not been cleansed unless they turn away from their wickedness, for it is unclean among all the transgressors of his word" (1QS V.10-11, 13-14).

We now know that the Qumran community was only one among a number of other utopian societies in the late Hellenistic world. ${ }^{22}$ The Essenes exhibited the same type of social organisation as the ideal and utopian societies written about by Iamboulos and Euhemeros. Some of the features they had in common with these utopian communities include strict isolation from the outside world, internal harmony, small community led by elders, community of goods, cooperation and equality, common meals, asceticism and special diet, uniformity of dress, antithesis to city life, a concern with purity and baptisms, opposition to marriage, the absence of a temple and a stark dualism. Whether realised or just existing on the level of ideology, this self-representation of the Essenes as a utopian society came at a time when the ideal of socially dissociated utopia became popular in the Hellenistic world.

If we survey the complex of purity-washing-moral coaching-social formation from Hellenistic utopian societies and fraternities, to the Essenes, to early Christian groups, it is not unwarranted to posit that we are dealing with a spectrum of possibilities within a limited range of similarities. One can, for instance, refer to the water lustrations and ritual baptisms as purificatory baths in the cult of Isis as partaking of the death and rebirth of the god - the same complex as encountered in Colossians with reference to baptism as incorporation into the death and resurrection of Christ, as well as the white garments worn by initiates to reflect the radiance of the god - compare this with Colossians/Ephesians: The putting on of the divine life as clothing (cf. the description of the process of initiation in Apuleius's Golden Ass). ${ }^{23}$ Simply put, we are looking at a common set of discursive

20 This accords with Ambrose's exposition in The Sacraments 4 (the eucharist following on the baptism), Traditio Apostolica 21 (baptism of newly initiated immediately followed by celebration of eucharist), and Cyril of Jerusalem Mystagogical Catecheses 4 (the celebration of the eucharist follows on the rite of baptism, so it seems from the way in which the instruction on the eucharist seamlessly follows on that on baptism).

21 "He will not become clean by the acts of atonement, nor shall he be purified by the cleansing waters, nor shall he be made holy by the seas and the rivers, nor shall he be purified by all the water of the ablutions" (1QS III.4-5); "And by the compliance of his soul with all the laws of God his flesh is cleansed by being sprinkled with cleansing waters and being made holy with the waters of repentance" (1QS III.8-9); "He will sprinkle over him the spirit of truth like lustral water (in order to cleanse him) from all the abhorrences of deceit and from the defilement of the unclean spirit" (1QS IV.21-22).

22 See Mendels (1979) and Ferguson (1979).

23 For a full discussion of nudity and change of clothing ("garments of shame") in Christian baptismal rituals and contemporary Judaism and other Graeco-Roman cults, see the essay "Garments of Shame" in Smith (1978, 1-23). 
techniques of making society/-ies within the larger context of the Graeco-Roman world and the early Roman Empire. ${ }^{24}$

A study of the rhetoric of inquiry would quickly demonstrate that this kind of comparison is a function - and a result - of our classificatory and definitional practices. If religion (and by extension, Christianity), is defined as a sui generis phenomenon, the Eliadean irruption of the sacred in the profane, then it is possible to isolate, on the one hand, the "religious phenomenon" (the ritual of washing) from the social ideologies and socially constitutive practices defining and rhetorically constituting context, and on the other hand, to isolate "Christian phenomena" from others, so as to assert that baptism is by nature something different from the ritual water washings demanded and performed in other religious cults of the times.

So the idea of purity and the accompanying washing as the graphic and emphatic cleansing of the body from the contamination emanating from the larger society, serves as a dissociative technique. In fact, the dissociation is so strong, in the case of the Community Rule, that the two societies, the Essene community and the rest of the Jewish religious community under the aegis of the temple authorities, are represented as being controlled by two different spirits, the spirit of truth and the spirit of deceit, both in turn part of the dominion of the Prince of Light and the Prince of Darkness. Simply put: The others against which the elect are demarcated off are demon possessed.

This is an aspect that re-occurs in early Christian baptismal liturgies. In the early third century Traditio Apostolica, for instance (but the phenomenon is well documented in other early Christian liturgies and descriptions of Christian initiatory processes), ${ }^{25}$ the to-be baptised in the process of being separated from the society they come from are anointed with oil, and have to foreswear the devil, as an act of exorcism (that is, being cut off from the One who controls the world), and after baptism, is again sealed with oil as protection against demonic invasion and control.

But the Traditio Apostolica goes one step further. After describing the moral scrutiny the initiand has to undergo in the process of being determined whether ready to be accepted and baptised, it lists a number of occupations that disqualify the neophyte from being baptised and incorporated into the Christian community, unless the neophyte desists from these occupations. The list is telling: No pimp or prostitute; no painter or sculptor (they might be involved in making idols); no actor (he may be involved in representing deities in theatre); no teacher of children; no gladiator or someone involved in arena sports; no priest or "idol attendant"; no soldier or magistrate; no magician or charm maker or interpreter of dreams, nor homosexual. Apart from including some morally proscribed categories that are also proscribed in other cults, it is telling that the occupations of soldier and magistrate are prohibited. On the whole, the proscribed occupations describe points of contact with broader society, but these specifically signal the dissociation of the Christian initiate from civil responsibilities (apart, of course, from the injunction against the taking of life). It is this aspect of early Christian dissociation from their civil context that provoked charges of cannibalism and incest. For, as Henk Versnel (1988a) has shown, these charges constituted a kind of labelling of these groups as anti-social forces of chaos. This is what was at issue

24 Cf. the earlier mentioned Hellenistic cult group whose "constitution" is preserved in the inscription from Philadelphia, Asia Minor, ca. $1^{\text {st }}$ century C.E. and published in Barton and Horsley (1981). Again one finds the connection with moral purity and social formation. For the phenomenon of voluntary societies see Kloppenborg and Wilson (1996).

25 Such as Cyril of Jerusalem's Mystagogical Catecheses, John Chrysostom's Baptismal Catecheses, and Egeria's Itinerarium with its description of the services of the Jerusalem octave - holy week celebrations over Easter. 
in the persecution of early Christian groups in the empire - they did not want to play the social and ideological game. They, quite frankly, undermined and endangered the empire.

More or less a century later, John Chrysostom could, in the Baptismal Catecheses, compare the putting on of the new clothes of the new life with wearing imperial uniforms:

3.1.45 Look at those administer governmental activities. Do you see how, whenever they are wearing clothing bearing the imperial images, they take pride in themselves and therefore they expect to be counted worthy of more honour and an armed escort? If indeed these expect to be venerable because they have the image lying on their robe, how much more does this hold for you who are about to put on Christ himself! ...

3.3.6 You, however - the new soldiers of Christ, those entered as citizens in heaven today, those summoned to this spiritual banquet and about to enjoy the imperial table ... 3.3.17. People who take up secular public services carry a portrait of the imperial images on the clothing they usually wear, and because of this they appear to everyone else to be trustworthy. They would certainly refuse to do anything that might be unworthy of this clothing that bears the imperial portraits. Furthermore, should they themselves attempt this, they have many who would prevent them, and should some others desire to treat them badly, they have the covering of the clothing as sufficient security against suffering anything odious. Given all this, consider those who have Christ himself, not on the robe but dwelling in their soul, along with the Father and the reception of the Holy Spirit: All the more they are duty-bound to show great circumspection and in everything to make manifest, through strict conduct and diligent attention to their manner of life, that they do bear the imperial image.

3.3.18. As they who display the imperial likenesses on their clothes over their breast stand out clearly to all, so also, if we should wish it, we who have put on Christ permanently and are worthy to have him dwell within, we are able wordlessly to demonstrate to all the power of the one who dwells within us through a strict way of life. As now the covering of your clothes and the brilliance of your robes attract everybody's eyes, so also, if you will it, by preserving the brightness of the imperial garment even more strictly than now through your strict conduct under God, you are able continuously to attract all who behold you to similar zeal and to the praise of the Master...

\section{Conclusion: Adaptations and Innovations}

The times have changed, the empire was now Christian, and baptismal initiation no longer implied purification as dissociation from society, and gradually a process was set in motion whereby the horizontal focus of social formation was replaced by a vertical focus on the individual incorporation into God. So this is my theory about the problem I started with, namely the difference between early Christian baptismal practices and discourse, Reformed baptismal theology, and contemporary folk understanding of baptism: Early Christian texts speak from and into a context of social formation, literally a context in which Christianity is still being manufactured and defined in opposition to the rest of the smorgasbord of GraecoRoman religious options. Both Reformed theology and contemporary folk understandings of baptism speak from and into a context where Christianity and society have become coextensive, so to speak. One does not have to dissociate from society to be a Christian, at least this is the case with historically mainline churches. Historical interpretations of baptism will not communicate in contemporary settings because the two sets of contexts are incompatible. So we can see how the way we conceptualise religion becomes visible in the way we perform a ritual action on a human body. 
We can take the phrase "religious discourse" to indicate not only the content of our speaking about religion, but also the selection and arrangement of what we want to say (heuresis and taxis), the logic governing the selection and presentation (i.e. theory both implicit and explicit), the social locations generating this logic and presentation, the imagined and envisaged purposefulness of the presentation, as well as the practices that embody these presentations and in turn authorise these understandings by conventionalising them in a kind of habitus or life-world. In this case the body is the site where religious discourse is materialised, and rhetoric is the configuration of representations and practices

that facilitate this materialisation.

\section{BIBLIOGRAPHY}

Barth, G 1981. Die Taufe in frühchristlicher Zeit. Neukirchen-Vluyn: Neukirchener Verlag. Barton, SC and Horsley, GHR 1981. A Hellenistic Cult Group and the New Testament Churches. Jahrbuch für Antike und Christentum 24:7-41.

Bell, C 1998. Performance. Pages 205-224 in Critical Terms for Religious Studies. Edited by M.C. Taylor. Chicago: University of Chicago Press.

---- 1992. Ritual Theory. Ritual Practice. New York: Oxford University Press.

---- 1988. Ritualization of Texts and Textualization of Ritual in the Codification of Taoist Liturgy. History of Religion 27(4):366-392.

Burkert, W 1987. Ancient Mystery Cults. Cambridge: Harvard University Press.

Cumpsty, J 1995. The Importance of Starting from both Ends: An Appreciative Response to Michael Pye's Keynote Address. Pages 18-39 in Religion and the Reconstruction of Civil Society. Papers from the Founding Conference of the South African Academy of Religion, January 1994. Edited by JW De Gruchy and S Martin. Pretoria: University of South Africa.

Ferguson, J 1979. Utopias of the Classical World. London: Thames and Hudson.

Goldberg, HE 1990. The Zohar in Southern Morocco: A Study in the Ethnography of Texts. History of Religions 29(3):233-258.

Hahn, F 1976. Die Taufe im Neuen Testament. Pages 9-28 in Calwer Predigthilfen. Taufe. Edited by H. Breit and M. Seitz. Stuttgart: Calwer Verlag.

Hunt, SJ 2003. Alternative Religions. A Sociological Introduction. Aldershot: Ashgate.

Kloppenborg, JS and Wilson, SG (eds.) 1996. Voluntary Associations in the Graeco-Roman World. London: Routledge.

Marjanen, A and Luomanen, P (eds.) 2005. A Companion to Second-Century Christian "Heretics." Leiden: Brill.

Mendels, D 1979. Hellenistic Utopia and the Essenes. Harvard Theological Review 72:207222.

Pretorius, H 2004. Drumbeats. Sounds of Zion in the Cape Flats. African Initiatives in Christian Mission 10. Pretoria: University of South Africa Press.

Pye, M 1995. Religion and Identity: Clues and Threads. Pages 3-17 in Religion and the Reconstruction of Civil Society. Papers from the Founding Conference of the South African Academy of Religion, January 1994. Edited by JW De Gruchy and S Martin. Pretoria: University of South Africa. 
Reed, JL 1996. The Sign of Jonah (Q11:29-32) and Other Epic Traditions in Q. Pages 130143 in Reimagining Christian Origins. A Colloquium Honoring Burton L Mack. Edited by EA Castelli and H Taussig. Valley Forge: Trinity Press International.

Reitzenstein, R 1956. Die hellenistischen Mysterienreligionen nach ihren Grundgedanken und Wirkungen. Stuttgart: Teubner.

Rudolph, K 1987. Gnosis. The Nature and History of Gnosticism. San Francisco: HarperSanFrancisco.

Seitz, M 1976. Die Predigt bei der Taufe. Pages 29-38 in Calwer Predigthilfen. Taufe. Edited by H Breit and M Seitz. Stuttgart: Calwer Verlag.

Smith, JZ 1978. Map is not Territory. Leiden: Brill.

Van den Heever, GA 2005. Loose Fictions and Frivolous Fabrications. Ancient Fiction and the Mystery Religions of the Early Imperial Era. PhD diss. Pretoria: University of South Africa.

--- 2002. "From the Pragmatics of Textures to a Christian Utopia": The Case of the Gospel of John. Pages 297-334 in Rhetorical Criticism and the Bible. Edited by SE Porter and DL Stamps. Journal for the Study of the New Testament: Supplement Series 195. London: Sheffield Academic Press.

---- 2001. On How to Be or Not to Be: Theoretical Reflection on Religion and Identity in Africa. Religion \& Theology 8(1\&2):1-25.

Versnel, HS 1988a. Geef de Keiser wat des Keisers is en Gode wat Gods is. Een Essay over een Utopisch Conflict. Lampas 21(3):233-256.

--- $\quad$ 1988b. Religieuze Stromingen in het Hellenisme. Lampas 21(2):111-136.

Watzlawick, P, Bavelas, J and Jackson, D 1967. The Pragmatics of Human Communication: A Study of Interactional Patterns, Pathologies and Paradoxes. New York: Norton.

Wenz, G 1998. Sakramente I. Kirchengeschictlich. Pages 663-684 in Theologische Realenzyklopädie 29. Edited by G Krause and G Müller. Berlin: De Gruyter.

Wuellner, W 1991. Rhetorical Criticism and its Theory in Culture-Critical Perspective: The Narrative Rhetoric of John 11. Pages 171-185 in Text and Interpretation. New Approaches in the Criticism of the New Testament. Edited by PJ Hartin and JH Petzer; New Testament Tools and Studies 15. Leiden: Brill. 